\title{
Reformacja w percepcji młodzieży licealnej na Śląsku Cieszyńskim
}

Streszczenie: Problematyka artykułu dotyczy percepcji wartości, jakie wypromowała i promuje Reformacja. Przedstawiam tło i genezę powstania ruchu reformacyjnego w Europie i na ziemiach polskich, pokazując dynamikę i zakres jego oddziaływania. Nakreślam istotę filarów Reformacji w rozumieniu teologicznym oraz postrzeganie i percepcję dziedzictwa Reformacji przez współczesną młodzież licealną na podstawie przeprowadzonego wywiadu skategoryzowanego.

Słowa klucze: Percepcja wartości Reformacji, młodzież z pogranicza polsko-czeskiego

\section{Aktualność dziedzictwa Reformacji}

Dzień 21 września 2008 roku przeszedł do historii jako dzień rozpoczęcia Dekady Lutra, gdy w kościele zamkowym w Wittenberdze przy udziale liderów luterańskich z całego świata, w tym prezydenta Światowej Federacji Luterańskiej a zarazem zwierzchnika Ewangelicko-Luterańskiego Kościoła Ameryki, ks. biskupa Marka S. Hansona oraz gości ekumenicznych, zainaugurowano nabożeństwem międzynarodowy projekt społeczno-religijny, którego celem jest popularyzowanie historii i dziedzictwa Reformacji zapoczątkowanej dnia 31 października 1517 roku właśnie tam, przez ks. dra Marcina Lutra, reformatora Kościoła Zachodniego (luter2017.pl, 2017). Kościół Ewangelicko-Augsburski w Rzeczypospolitej Polskiej włączając się w Dekadę Lutra, równocześnie partycypuje w inicjatywach przybliżania Polakom, bez względu na wyznanie, dorobku reformacji luterańskiej w Polsce i na całym świecie (luter2017.pl, 2017), którego potencjał znajduje swoje odzwierciedlenie na płaszczyźnie duchowej wybitnych jednostek, jak i społeczeństw, kształtując postawy, ukierunkowując dokonywanie wyborów czy motywując do działania. „Dla ewangelików tradycji luterańskiej, ale także dla chrześcijan, dla których dziedzictwo Reformacji jest nieodłącznym elementem ich duchowej tożsamości" (luter2017.pl, 2017). Rok Reformacji zainaugurowany 
globalnie w Lund w Szwecji, dnia 31 października 2016 roku, ma szczególne znaczenie. Bowiem reformacja to odnowa, to ponowne kształtowanie, które wymaga konfrontacji z zagadnieniem percepcji wartości, wówczas ponownie powołanych do życia, a po pięciuset latach nadal stanowiących źródło i fundament wiary chrześcijańskiej. I jak stwierdza ksiądz Jan Badura, emerytowany duchowny Kościoła Ewangelicko-Augsburskiego w RP, w wywiadzie otwartym dotyczącym postrzegania przez duchownych zagadnienia percepcji Reformacji wśród młodzieży, przeprowadzonym dnia 19. stycznia 2017 roku: „Pokłosiem Reformacji jest powrót do źródła chrześcijańskiej wiary, czyli Pisma Świętego. Studiowanie Słowa Bożego przynosi i współcześnie rozwój jednostki w sensie pozytywnego podejścia do życia, odpowiedzialnego traktowania codziennych obowiązków a także rozbudowuje etos pracy w jak najszerszym tego słowa znaczeniu”. Ksiądz Łukasz Stachelek, jako duchowny troszczący się o młode pokolenie, skonfrontowany z powyższym zagadnieniem w wywiadzie otwartym $\mathrm{z}$ dnia 14. marca 2017 roku podkreśla, że „współczesna młodzież identyfikuje się z byciem ewangelikiem oraz z wartościami, które wniosła Reformacja”, wskazując równocześnie na znaczenie rodziny, gdyż "są to osoby, które były do tego przygotowywane przez rodziców i dziadków w domach rodzinnych". Zdaniem księdza Andrzeja Wójcika, "młodzi ludzie pomimo tego, że nie rozumieją jeszcze do końca potrzeby identyfikacji, tożsamości, podświadomie doceniają porządek i zasady”. Ksiądz Wójcik, w wywiadzie otwartym przeprowadzonym dnia 22. marca 2017 roku, zwraca również uwagę na fakt, iż „młodzież wyrasta na zupełnie innej niż nasza podbudowie otoczenia, biorąc pod uwagę czynniki wpływające na ogólny rozwój, a co za tym idzie, również szeroko pojętych wartości”. Jednak, jak zauważa ksiądz Wójcik: „Paradoksalnie Reformacja ze swoimi zasadami jest dla młodych atrakcyjnym zagadnieniem, bo kojarzy się z rozwojem, buntem, który sami często przechodzą. Reformacja, jak mawiamy, uwolniła Biblię, ale również nadała nową, uwolnioną przestrzeń - obszar poszukiwania duchowości i samego siebie". Ksiądz Mirosław Czyż dostrzega fakt, jak podaje w wywiadzie otwartym przeprowadzonym dnia 25. marca 2017 roku, że „reformacja może przybierać piękne ramy zewnętrzne, ale tak naprawdę chodzi o ciągłą „reformację serca i umysłu”. Im więcej osób młodszych i starszych uda się uwrażliwić na tę „reformację serca i umysłu”, stwierdza ksiądz Czyż, tym bardziej młodzi luteranie staną się świadomi swojej tożsamości i tym bardziej będą chcieli żyć według prawd, które na nowo odkrył ksiądz Marcin Luter". 


\section{Tło i geneza Reformacji}

„Pod koniec średniowiecza coraz wyraźniej zarysowywał się przekwit i upadek ówczesnego Kościoła" (Wojak, 1995, s. 45), który angażując się w życie polityczne, coraz intensywniej partycypował w procesie sekularyzacji. Świeckie ambicje ówczesnych postaci wiodących usprawiedliwiały precedens nepotyzmu oraz popularyzowały zjawisko symonii. „Ten stan rzeczy wywołał opozycję wewnątrz Kościoła, która przejawiała się w formie różnych ruchów religijno-moralnych" (Wojak, 1995, s. 46). W krajach Europy zachodniej, takich jak Włochy, Francja, Hiszpania i Niemcy, w XII wieku katarowie domagali się dobrowolnego ubóstwa i stosowali surową ascezę. Waldensi, zwolennicy poglądów Francuza Piotra Waldusa, koncentrowali się na łasce Bożej, objawionej w Chrystusie, która przynosi zbawienie. W roku 1229 synod w Tuluzie powołał do życia inkwizycję, czyli trybunał duchowny reprezentowany przez dominikanów, który miał tępić wszelkie nielegalne ruchy religijne. W tym okresie wprowadzono również zakaz czytania Pisma Świętego przez laików, który obowiązywał do XIX wieku. Jednak wybitni przedstawiciele Kościoła domagają się powrotu do zwiastowania zapomnianej Ewangelii. Profesor Oksfordu, Jan Wiklif, pragnąc udostępnić i upowszechnić Biblię, dokonuje w 1381 roku jej przekładu na język angielski. W Polsce jego zwolennikiem był profesor Uniwersytetu Jagiellońskiego Andrzej Gałka, a w Czechach, profesor teologii na uniwersytecie w Pradze Jan Hus. Również w XIV wieku angielski franciszkanin Wilhelm Ockham, późniejszy profesor w Oxfordzie, zapoczątkował nowy prąd umysłowy, który stawiając w centrum uwagi Bożą wolę, odegrał znaczną rolę w późniejszym rozwoju chrześcijaństwa (Wojak, 1995).

Zgodnie jednak z myślą Vivian Green (2000, s. 11) „warto zastanowić się także, jakie czynniki w ówczesnej sytuacji można byłoby uznać za przyśpieszające rozwój reformacji”? Bowiem wiek XV mieni się okresem ożywionego rozwoju intelektualnego, znajdującego swoje źródła w starożytnej kulturze i literaturze dawnych wieków. W dziejach chrześcijaństwa odegrało rolę głoszone wówczas hasło ad fontes - do źródeł, pobudzając zainteresowanie dziełami Ojców Kościoła oraz inspirując do czytania Pisma Świętego w oryginale. W odrodzeniu intelektualnym największą rolę odegrał niderlandzki uczony Erazm z Rotterdamu, który przetłumaczył Nowy Testament z języka greckiego na język łaciński (Wojak, 1995). Piśmiennictwo oraz umiejętność czytania rozwijały się w licznie powstających szkołach średnich i uniwersytetach, gdzie oprócz łaciny nauczano języka ojczystego. Rok 1450 zapisał się na kartach historii jako 
rok udoskonalenia i skonstruowania przez Jana Gutenberga z Moguncji czcionki, a zastosowanie druku umożliwiło powszechną dostępność broszur, pism i książek. Około roku 1455 wydał wydrukowaną dwutomową, tzw. 42-wierszowa Biblię łacińska (Dahl, 1965). Z dorobku naukowego starożytnej Grecji, pitagorejczyka Filolaosa (Adamczewski, 1972) zaczerpnął również Mikołaj Kopernik, którego dzieło O obrotach sfer niebieskich przedstawiające koncepcję heliocentryzmu spowodowało upadek systemu geocentrycznego, wpływając diametralnie na zmianę sposobu myślenia i patrzenia na świat. Wielkie odkrycia geograficzne, między innymi dotarcie w 1492 roku Krzysztofa Kolumba do kontynentu Ameryki, wywołały znaczące przemiany w życiu społeczeństw z jednej strony, z drugiej zaś, świat żył pod groźbą inwazji tureckiej, co wpływało na uleganie nastrojom eschatologicznym, gdyż „obawiano się zagłady świata” (Wojak, 1995, s. 56). „Wkrótce miały nadejść zmiany burzące istniejącą strukturę Kościoła, kształtujące na nowo jego nauki, a także wprowadzające nowy ład społeczny i polityczny" (Green, 2000, s. 14). Zwrot do źródeł Ewangelii oraz nowe zainteresowanie podstawowym tekstem Nowego Testamentu miały dla chrześcijaństwa największe znaczenie, a tym samym stanowiły w XV wieku tło dla Reformacji (Wojak, 1995).

\section{Istota Reformacji}

Wiekiem Reformacji był wiek XVI, a centralną postacią pierwszego okresu jest Marcin Luter, augustianin, którego teologia wyrosła „z nieustającego obcowania z Bożym Słowem” (Uglorz, 1995, s. 11). Początkowo wykłada w katedrze filozofii moralnej w nowo założonym w 1508 roku Uniwersytecie w Wittenberdze, a w późniejszym czasie jako doktor nauk teologicznych, obejmuje Luter katedrę biblistyki, i właśnie na płaszczyźnie teologicznej, niewątpliwie powiązanej z myślą teologiczną pierwotnego chrześcijaństwa, walczy o nowe oblicze Kościoła. Publiczną trybuną haseł Reformacji stała się jednak ambona, z której rozlegało się zwiastowanie Ewangelii porywającej i rozsadzającej stare struktury pobożności (Uglorz, 1995).

Myśl teologiczną dra Marcina Lutra można streścić w czterech hasłach: sola Scriptura - jedynie Pismo, solus Christus - jedynie Chrystus, sola gratia per fidem - jedynie z taski przez wiarę, solum Verbum - jedynie słowo (Uglorz, 1995). Zasadnym jednak wydaje się postawienie pytania: Dlaczego właśnie takie hasła stały się filarami nauki reformacyjnej? Poszukując więc praźródła kształtującego normy życia i postępowania starożytnego Kościoła, właśnie Słowo Boże stanowiło ich jedyną podstawę, w odróżnieniu do Kościoła średnio- 
wiecznego, w którym wyznacznikiem wiary i życia chrześcijańskiego, obok Biblii, była tradycja. Czerpano więc ze skarbca i tradycji kościelnej odwołując się do poglądów poszczególnych osób lub zgromadzenia, lecz Luter podkreślał konieczność odwoływania się do autorytetu wyższego aniżeli ludzka myśl czy przekonanie. „Jedynie pewnym i niezawodnym autorytetem, źródłem wiary i normą postępowania chrześcijańskiego, według Lutra, może być i jest Słowo Boże, Biblia, nie myli się bowiem przemawiający przez jej karty Bóg” (Uglorz, 1995, s. 126). Przebywając na zamku w Wartburgu Marcin Luter dokonuje w latach 1521-1522 tłumaczenia Nowego Testamentu z języka greckiego na język narodowy. Przekład Starego Testamentu z języka hebrajskiego zajął reformatorowi dwanaście lat. Całe tłumaczenie Biblii ukazało się drukiem w 1534 roku (Green, 2000), stając się codzienną lekturą dla chrześcijan, a hasło: jedynie Pismo „zasadą określającą źródło i fundament wiary, nauki i teologii” (Uglorz, 1995, s. 123). Istotą i treścią wiary reformacyjnej, więcej, całej teologii chrześcijańskiej jest chrystologia, czyli nauka o Chrystusie, Synu Bożym. W centrum myśli wittenberskiej reformacji została postawiona soteriologia, czyli nauka o zbawieniu dokonanym w Jezusie Chrystusie. Wittenberski Reformator znalazł łaskawego Boga w ukrzyżowanym Synu Bożym, a formułując zasadę solus Christus postawił sobie za cel wskazywać na krzyż, bowiem w centrum jego uwagi oscylowało dzieło Chrystusa i wszystkie aspekty Jego śmierci na krzyżu. Śmierć Chrystusa na Golgocie była nie tylko ofiarą przebłagalną złożoną Bogu, ale jest darem Bożym dla człowieka, a w nim pojednanie, wyzwolenie, usprawiedliwienie. Soteriologia Lutra jest teologią krzyża, z której wypływa całe reformacyjne zwiastowanie, które jest zwiastowaniem sądu i łaski, objawieniem Bożej łaski i Bożego gniewu. Boży gniew dotknął Jezusa, gdyż na Niego został złożony grzech świata. Na Golgocie zatem dokonał się sąd na sprawiedliwym Bożym Synu. „Gniew Boży z powodu grzechów człowieka spotkał Chrystusa, łaska zaś z powodu posłuszeństwa i sprawiedliwości Chrystusa okazana została człowiekowi" (Uglorz, 1995, s. 135).

W soteriologicznych rozważaniach Lutra zasada solus Christus podkreśla suwerenność Boga i konstatuje, że zbawienie człowieka jest wyłącznym dziełem Boga w Jezusie Chrystusie. Jedynie Chrystus, jedynie Syn Boży jest Zbawicielem i pośrednikiem między człowiekiem a Bogiem. Z tą pryncypialną zasadą łączy się, a właściwie jest jej częścią składową reformacyjne hasło sola gratia. Bowiem centralnym tematem teologicznym księdza dra Marcina Lutra jest nauczanie i zwiastowanie o usprawiedliwieniu człowieka z łaski przez wiarę - sola gratia per fidem. „Niesprawiedliwy człowiek zostaje z łaski uznany przez Boga za usprawiedliwionego i jest mu darowana sprawiedliwość 
Chrystusa" (Uglorz, 1995, s. 141). Usprawiedliwienie jest więc darem Bożym. Czym jest, wobec powyższego, wiara w rozumieniu reformacyjnym? Wiara, to zaufanie łaskawemu Bogu, przez wiarę, której sprawcą jest Chrystus, człowiek przyswaja sobie darowane mu przez Boga usprawiedliwienie „wysłużone przez Chrystusa" (Uglorz, 1995, s. 143). Percepcja zbawienia jest więc możliwa jedynie dzięki interwencji Bożej. Bóg przemawia do człowieka przez swoje Słowo, którego efektem słuchania jest właśnie wiara. Słowo Boże to Zakon, który daje człowiekowi poznanie grzechu i jego duchowej niemocy, a także Ewangelia, która zwiastuje grzesznikowi odpuszczenie win i kary i prowadzi człowieka do Chrystusa. Jedynie przez Słowo Boże - solum Verbum - „Duch Boży czyni wierzącego nowym stworzeniem w Chrystusie" (Uglorz, 1995, s. 150). Podobnie o istocie Kościoła i jego wartości stanowi jedynie Stowo Boże. Doktor Marcin Luter głosząc swe poglądy dążył do odtworzenia tego, co było istotą i treścią nauczania pierwotnej wspólnoty chrześcijańskiej (Green, 2000), stał się jednak „twórcą reformacyjnej teologii i natchnieniem dla wielu pokoleń ewangelickich teologów" (Uglorz, 1995, s. 123).

\section{Rozprzestrzenianie się Reformacji}

Dzień 31 października 1517 został uznany za dzień zrodzenia się nowej doktryny teologiczno-moralnej, kiedy to profesor dialektyki, etyki, egzegezy i doktor teologii Marcin Luter przybił na drzwiach kościoła wittenberskiego 95 tez. Poglądy Lutra rozprzestrzeniały się w zaskakującym tempie, i to nie tylko w Niemczech, ale także poza ich granicami. Przesłanie Reformacji docierało do licznych odbiorców za pośrednictwem wędrownych kaznodziejów, a także poprzez drukowane broszury (Green, 2000). Antycypacja zasady cuius regio eius religio przez książąt niemieckich w 1555 roku w Augsburgu, wprowadziła w Niemczech pragmatykę wyznawania na terytorium danego księstwa wyznania, które przyjął panujący tam książę (Green, 2000).

Luteranizm stanowiąc główny nurt niemieckiego protestantyzmu trafia do Anglii, w której wiele idei Lutra zostaje przejętych przez arcybiskupa Cranmera (Green, 2000), który za czasów króla Henryka VIII zmuszony był do opuszczenia kraju. Przebywając w Wittenberdze przekłada Nowy Testament na język angielski. W kraju opracowuje również Modlitewnik powszechny oraz formułuje w 1552 roku wyznanie wiary, które ma już cechy kalwińskie. Reformacja w Szkocji szerzyła się wśród szlachty, a duchowym przywódcą jej zwolenników był John Knox. Jako prezbiterianizm zachowała się wśród ludu szkockiego (Wojak, 1995). 
Pisma reformatora studiowano i przyjmowano również w krajach skandynawskich, w których luteranizm zakorzenił się na stałe. W Danii czołowym przedstawicielem był Hans Tausen, zakonnik studiujący w Wittenberdze, a potem szerzący w swoim kraju zreformowaną religię. W 1529 roku w Kopenhadze zebrało się Zgromadzenie Narodowe, które zatwierdziło reformy oraz sformułowało protestanckie wyznanie wiary, tzw. Herredag. Król duński Fryderyk I, udzielając poparcia możnowładcom, przyczynił się do zwycięstwa luteranizmu w kraju, a jego następca, Chrystian III, poprowadził i kontynuował reformację duńską (Green, 2000), wprowadzając w życie w roku 1530 Konfesję kopenhaską stanowiącą podstawę nauki Kościoła Ewangelickiego (Wojak, 1995). W Szwecji, Gustaw Waza, który wywalczył niezależność kraju od konfederacji państw skandynawskich, jako Gustaw I powołał do współpracy kaznodziejów protestanckich. Kanclerzem królewskim a zarazem wykonawcą przemian doktrynalnych został Olaf Petri, a jego brat, Laurenty Petri, pierwszym protestanckim biskupem Uppsali i autorem przekładu Nowego Testamentu na język narodowy. W następnym stuleciu głównym przywódcą protestantyzmu w Szwecji okazał się król Gustaw Adolf (Green, 2000). Przenikanie reformacji luterańskiej do Niderlandów rozpoczęło się stosunkowo wcześnie, i już w 1523 roku wydano w Amsterdamie Nowy Testament w języku holenderskim. Przenikanie reformacji typu kalwińskiego do kraju, zaowocowało w 1566 roku ogłoszeniem w Antwerpii Confessio Belgica, czyli niderlandzkiego wyznania wiary w duchu kalwińskim (Wojak, 1995).

Dzieła Lutra, a potem Kalwina wzbudziły również zainteresowanie francuskich humanistów. Przekład Nowego Testamentu we Francji wydał sławny uczony Faber Stapulensis, a w 1559 roku na synodzie ewangelickim w Paryżu przyjęto Confessio Gallicana. Autorem aktów, wyznania wiary i statutu, był Jan Kalwin (Wojak, 1995), którego podstawowe dzieło Institutio religionis christianae - Nauka religii chrześcijańskiej przypomina Katechizm Lutra. Dla reformatora „podstawą nauki chrześcijańskiej było Słowo Boże, a jego jądrem nauka o usprawiedliwieniu. Wiara jest darem Boga, prowadzi ona do skruchy, do krzyża i do pewności zbawienia" (Wojak, 1995, s. 71).

Działalność swoją rozwinął jednak Kalwin w Szwajcarii, powołany przez Radę Miasta do realizacji zasad Reformacji w życiu publicznym i prywatnym mieszkańców Genewy (Wojak, 1995). Bowiem szwajcarska reformacja rozwijała się równolegle z reformacją luterańską, a jej inicjatorem był duchowny Ulryk Zwingli, którego instalacja na proboszcza w Zurychu nastąpiła dnia 1 stycznia 1519 roku. Dzień ten ma dla Kościoła Ewangelicko-Reformowanego takie samo znaczenie jak 31 października 1517 roku dla Kościoła 
Ewangelicko-Augsburskiego. Zaczątkiem uniwersytetu w Zurychu stała się szkoła biblijna, którą założył Zwingli dążąc do upowszechniania Słowa Bożego. Mając na względzie dostępność Biblii także dla wiernych, wydaje w 1529 roku przekład ksiąg prorockich Starego Testamentu, a w 1531 roku całe Pismo Święte. Rok 1529 przynosi jeszcze jedno ważne wydarzenie, dochodzi mianowicie do spotkania Zwingliego z Lutrem oraz ich współpracowników w Marburgu, gdzie uzgodniono podstawowe założenia Reformacji (Wojak, 1995). Niemniej jednak zwinglianizm, który dał początek różnym nurtom $\mathrm{w}$ protestantyzmie i odegrał istotną rolę w reformacji w Szwajcarii, został wchłonięty przez kalwinizm, co znalazło swoje potwierdzenie w ugodzie zuryskiej Consensus Tigurinus (Green, 2000).

Kalwinizm w Polsce rozwijał się obok luteranizmu i reformacyjnego kierunku braci czeskich. Uwagę wybitnego teologa i humanisty Jana Łaskiego na Pismo Święte skierował Ulryk Zwingli podczas ich osobistego spotkania. Łaski wywarł duży wpływ na ewangelików zamieszkujących Małopolskę, którzy później związali się z poglądami reformatorów szwajcarskich. Wybitnym dziełem tego okresu jest Postylla Mikołaja Reja, czyli tom kazań wydany w roku 1557, cieszący się ogromną popularnością, a później także wielokrotnie wznawiany (Floryńska-Lalewicz, 2005). Pisma Lutra natomiast znalazły się w Krakowie już w roku 1520, a za sprawą docenta Uniwersytetu Jagiellońskiego Jakuba z Iłży, działającego w duchu reformacyjnym, wpływały na młodzież akademicką. Protektorami haseł reformacyjnych w Wielkopolsce były rody Ostrorogów, Leszczyńskich i Zbąskich, a pod patronatem magnackiego rodu Górków działali w Poznaniu Jan Seklucjan i Andrzej Samuel (Wojak, 1995). W dobie reformacji w Księstwie Cieszyńskim rządy sprawował książę Kazimierz II, który był przychylny nowemu ruchowi religijnemu. Kiedy w roku 1545 książę Wacław Adam przejmował władzę, większość tutejszej ludności była protestancka, więc wprowadzenie nowego porządku kościelnego zaowocowało też przeprowadzeniem reformy opartej o Pismo Święte (Kubica-Heller, 1996). To, że Śląsk Cieszyński jest największym skupiskiem polskich protestantów zawdzięczamy XVI-wiecznej Reformacji, która utorowała drogę Ewangelii (Zieliński, 1992).

\section{Percepcja Reformacji wśród młodzieży ze Śląska Cieszyńskiego}

Podejmując się zbadania zagadnienia percepcji Reformacji wśród współczesnego młodego pokolenia, przeprowadziłam w 2017 roku wśród uczniów 
z klas I-III wywodzących się z takich miejscowości jak: Cieszyn, Ustroń, Wisła, Skoczów, i uczęszczających do II Liceum Ogólnokształcącego im. M. Kopernika w Cieszynie wywiad skategoryzowany składający się z dziesięciu pytań.

Interesowały mnie takie zagadnienia jak: zrozumienie samego słowa „reformacja”, kojarzenie wydarzeń historycznych związanych z Reformacją, jej przyczyn i następstw, a także promowane i wyznawane wartości, ich charakter oraz ich oddziaływanie na kształtowanie osobowości młodego człowieka, dokonywanie wyborów jak i postawy życiowe, znajdujące swoje źródło w tekstach Pisma Świętego. Cytowane wypowiedzi badanej młodzieży są podane w oryginalnym brzmieniu i pisowni.

Młodzież ze Śląska Cieszyńskiego rozumie Reformację jako zmianę, zlikwidowanie czegoś, co już było i wprowadzenie czegoś nowego, odnowienie czegoś bez bezmyślnego przyjmowania zasad, wykonanie kroku do przodu. W swoich wypowiedziach młodzież podkreślała zaangażowane odważne działanie, które przyczyniło się do zmian oraz odnowy chrześcijaństwa i Kościoła poprzez zreformowanie niektórych zasad i praw na takie, które bliższe są prawdom zawartym w Biblii i woli Boga. Zmiany zapoczątkowane przez Reformację większość młodzieży kojarzy z przybiciem 95 tez przez księdza Marcina Lutra na drzwiach kościoła w Wittenberdze, przetłumaczeniem Biblii na język ojczysty, z innym podejściem do odpuszczania grzechów, ale także ze spaleniem bulli papieskiej, z Pokojem w Augsburgu, Nocą św. Bartłomieja czy wojną trzydziestoletnią.

Ruch reformacyjny pojawił się, zdaniem badanych, ponieważ Luter spojrzał na sytuację duchową swoich czasów z szerszej perspektywy. Chciał, aby nie tylko wybrani mieli dostęp do Pisma Świętego, ale także prości ludzie mogli zbliżyć się do Boga i pokochać Go, dlatego przetłumaczył Biblię. Także w wyniku niezgody „na zastane obowiązujące praktyki płacenia za odpuszczenie grzechów, co było niezgodne z Biblią". Podstawą ruchu była chęć ulepszenia bądź wyeliminowania niepotrzebnych doktryn, zmiany i odnowy społeczeństwa i Kościoła, przywrócenia władzy Boga oraz przypomnienie o Jego prawdziwej naturze, że jest miłosierny i przebacza grzechy bez względu na pieniądze. Przekazanie ludziom prawd wiary i Ewangelii. Reformacja stała się początkiem odnowy wiary, nauki i życia w oparciu o Boże Słowo, wniosła porządek, stabilność duchową i odnowiła miłość ludzi do Boga. Ukazała, że Bóg jest miłosiernym Ojcem, którego nie trzeba się bać, gdyż kocha nas w takim stopniu, że był w stanie poświęcić swojego Syna. „Nie chce nas karać, On chce nas mieć u siebie". Reformacja przypomniała ludziom, co tak naprawdę jest najważniej- 
sze w wierze, że tylko Bóg jest w stanie odpuszczać grzechy. Wniosła także elementarne filary wiary, na których opieramy się do dnia dzisiejszego. Wskazała na ważność relacji Bóg - człowiek i ukazała możliwości, które Bóg daje człowiekowi, mianowicie możliwość przeżywania bliskiej z Nim relacji. Bóg stał się przystępnym dla człowieka. Zdaniem badanych, reformacja umożliwiła poznawanie Boga w Jego Słowie dostępnym w językach narodowych i zbliżenie się do Niego. Znajdowanie w Biblii wsparcia i słów bezpośrednio skierowanych do człowieka. Skupienie na Chrystusie w Kościele, wolność duchową w Bogu, ale także podział i powstanie nowych wyznań, co daje możliwość wyboru.

Wśród najistotniejszych wartości będących dziedzictwem Reformacji młodzież wymienia cztery zasady Reformacji: sola Scriptura, solus Christus, sola gratia per fidem oraz solum Verbum. Zasada tylko Chrystus jest najcenniejszą wartością, „gdyż przyjmując Go do naszego serca i wierząc w Niego oraz Jego męczeńską śmierć na krzyżu możemy zostać zbawieni. Jest On bramą, przez którą należy przejść do Boga". Młodzież podkreśla znaczenie wiary w Boga, gdyż człowiek może być zbawiony tylko przez wiarę w Niego, dlatego że Bóg okazuje człowiekowi łaskę. Posłuszeństwo Bogu i miłość do Niego jest integralną częścią osobistej relacji z Nim. W takiej relacji człowiek ma możność rozmowy z Bogiem, w której prośba o przebaczenie i zaproszenie Jezusa do serca ma zbawienne znaczenie. Podkreślone jest również znaczenie Pisma Świętego, głównie Ewangelii będącej istotną częścią życia ewangelików: „Powinniśmy czytać Boże Słowo i czerpać z niego wskazówki do poprawy życia w zgodzie z Chrystusem”. Dostępność Biblii i „prawo poznawania prawdy Bożej” w swoim języku, wspólnota i pomoc innym, są dla wielu badanych istotnym dziedzictwem Reformacji. Wartości, które wniosła Reformacja młodzież uważa za ponadczasowe, ponieważ „pochodzą one z Biblii, która zawsze jest taka sama. Dotyczą Boga, który jest jedynyi niezmienny”. „Dla chrześcijan Pismo zawsze będzie zawierało wskazówki do poprawnego życia, zbawienie zawsze będziemy mogli uzyskać tylko z łaski przez wiarę, a Chrystus zawsze dla chrześcijan powinien być jedynym i wszechmocnym Bogiem”. „Wszyscy wierzący, idący za Bogiem, powinni się ich trzymać, czy teraz czy za kilkanaście lat, bo Pan się nie zmienia, podstawa naszej wiary również”. „Dla Boga czas się nie zmienia, dlatego te wartości obowiązują nas nadal” „i pewnie będą stosowane w przyszłości, ponieważ są stworzone dla każdego człowieka", każdy bowiem „potrzebuje prawdziwej wiary”. „Wartości te są ponadczasowe, ponieważ Bóg jest nieskończony i będzie panował już na zawsze, tak jak i Jego przykazania oraz wartości, które każdy człowiek powinien mieć w sercu i wcielać w każdy swój dzień”. 
Młodzież jest również zdania, że wymieniane wartości kształtują osobowość, charakter, także światopogląd poprzez nadanie właściwego kierunku dokonywania wyborów. Pojawia się samoświadomość popełniania błędów i grzechu oraz świadomość potrzeby nawrócenia, a co za tym idzie naprawy życia i postępowania, prowadzenia prawego życia. Osoba uwrażliwiona zostaje na sposób traktowania bliźnich, przyjmuje postawę miłości, dobroci i wyrozumiałości, podarowania innym drugiej szansy. Kształtowana jest również pokora i postrzeganie samego siebie jako Dziecka Bożego konsekwentnie kroczącego Bożym śladem oraz uczącego się cierpliwości. Osobowość kształtuje się również poprzez zaufanie Bogu, że „wszystko, co On zaplanuje” jest dla człowieka dobre i prowadzi do zbawienia i życia wiecznego u Jego boku.

Na wybory i postawy życiowe młodych spadkobierców Reformacji oddziaływają wszystkie z wymienionych wartości reformacyjnych, „ponieważ wszystkie się ze sobą łączą i tworzą piękną całość i harmonię". Zasada tylko Chrystus pozwala przebaczać i kochać oraz okazywać Mu zawsze wdzięczność. Wartość tylko Słowo pomaga kierować się w życiu Słowem Pana, postępować według Jego przykazań, okazywać posłuszeństwo wobec rodziców, wyzwala mówienie prawdy i wybór dobra. Wypiera egoizm a nakierowuje na wspieranie bliźnich. Wzbudza chęć podobania się Bogu. Wśród treści i wartości reformacyjnych, które badana młodzież chciałaby przekazać następnemu pokoleniu, na pierwszym miejscu postawiona została wiara w Boga, w to, „że Jezus umarł za nas na Krzyżu, po to, byśmy mogli dostąpić żywota wiecznego", wreszcie wiara w zmartwychwstanie Jezusa Chrystusa. Miłość i zaufanie do Niego oraz ważność czytania i kierowania się w życiu Bożym Słowem, w którym można znaleźć odpowiedzi na każde nurtujące nas pytanie, pocieszenie i pomoc. Swoim dzieciom chciałaby młodzież „pokazać, ile znaczy wiara w życiu człowieka”, zachęcić „aby powierzyli Mu swoje życie” „i by byli Mu wierni”. Za podstawę i źródła swoich wypowiedzi badana młodzież podaje Biblię, Mały i Duży Katechizm dra Marcina Lutra, treści Ewangelii, Ewangelii św. Jana czy też św. Mateusza, Listów św. Piotra oraz św. Pawła do Efezjan i Tymoteusza, Objawienie św. Jana, Księgę Izajasza, Tezy księdza dr. Marcina Lutra, podręczniki do historii, treści przekazywane w czasie nabożeństw i lekcji religii, czasopismo ewangelickie Zwiastun, Internet, a także swoje własne przekonania i poglądy.

\section{Konkluzje}

Dążąc do konstatacji postrzegania współczesnej percepcji Reformacji oraz jej treści wśród młodzieży cieszyńskiej, skonfrontowałam duchownych Ko- 
ścioła Ewangelicko-Augsburskiego w Rzeczypospolitej Polskiej oraz młodzież uczącą się w jednym z liceów na terenie Śląska Cieszyńskiego z powyższym zagadnieniem. Ksiądz Łukasz Stachelek podkreśla w wywiadzie „istotne znacznie roli duchownego i katechety, którzy mają wiele narzędzi do tego, by w ciekawy sposób przedstawiać Reformację oraz jej znaczenie dla naszej teraźniejszości i przyszłości i w ten sposób poszerzać grono młodych ewangelików, którzy chcą i identyfikują się z dziedzictwem Reformacji”. Duchowny, ksiądz Andrzej Wójcik w swojej wypowiedzi zwraca uwagę na to, „jak ważne jest towarzyszenie młodzieży w sprawdzeniu reformacyjnych biblijnych wartości, które kształtują młode charaktery i wychowują do dobrego. To „sprawdzanie” może przynieść owoce, jeśli tylko pozwolimy na samodzielność i kreatywność". Znaczenie roli katechetów, jako przewodników młodzieży w uzgadnianiu znaczeń, sensów i wartości, podkreśla też Aniela Różańska (2015). Młodzi ludzie, jak wskazują badania, chcieliby w dyskusjach prowadzonych na lekcjach religii „nawiązywać do swoich poszukiwań egzystencjalnych i doświadczeń życiowych, a to stawia nauczyciela katechetę w roli kogoś, kto będzie im towarzyszył w tych poszukiwaniach i tworzeniu sensów oraz nadawaniu różnym zjawiskom, w tym religii, określonej wartości" (Różańska, 2015, s. 417). Zdaniem księdza Mirosława Czyża, zaczerpniętym z wywiadu, są młodzi ludzie, „dla których Bóg, Biblia, łaska, wiara, grzech, sakrament, reformacja - to nie są puste słowa”.

Potwierdzeniem głębi zrozumienia i przeżywania istotności tych wartości w życiu współczesnych młodych ludzi są sprecyzowane przez nich samych myśli oraz przekonania, które potrafią wyrazić i opisać. Cytując je i analizując mogę wysnuć wniosek, że wartości, które promuje Reformacja uzdalniają młode pokolenie do poszukiwania duchowości i mają ogromny wpływ na reformację serca i umysłu. Mimo, iż upłynęło pięćset lat człowiek potrafi powiedzieć, że w życiu najistotniejsze jest osobiste poznanie Boga, że łaska Boża jest darem, przebaczeniem, że wiara jest podstawą zbawienia i siłą do życia, a Słowo Boże przekonuje i uczy. Zatem percepcja Reformacji dokonuje się zarówno w wymiarze intelektualnym, jak i duchowym, wpływając na świadomość siebie i postawy wobec wyróżnionych wartości

Uwzględniając szeroki wachlarz wypowiedzi młodzieży konstatuję, iż badani reprezentują nad wyraz dojrzałe postawy charakteryzujące osobowości o ukształtowanej tożsamości religijnej, świadome wartości Reformacji, które dla nich samych mają charakter ponadczasowy. Ponadto współcześni podkreślają ważność i deklarują wolę promowania tychże wartości, równocześnie odwołując się do sfery uczuciowo-emocjonalnej człowieka. Młode pokolenie 
chce zasadzać swoją wiarę na miłości i zaufaniu do Boga, wierności Jemu i Jego Słowu. Postrzegam tu uchwycenie istoty i głębokie zrozumienie Reformacji, bowiem percepcja jej wartości znajduje także i współcześnie swój wyraz w pragmatyce życia młodych ludzi, warunkując oraz determinując ich myślenie i działanie.

\section{Bibliografia}

Adamczewski, J. 1972. Mikołaj Kopernik i jego epoka. Warszawa: Wydawnictwo Interpress.

Dahl, S. 1965. Dzieje książki. Kraków: Wydawnictwo Ossolińskich.

Floryńska-Lalewicz, H. 2005. Artyści z kategorii literatura. Mikołaj Rej. http:// culture.pl/pl/tworca/mikolaj-rej (4.02.2017).

Green, V. 2000. Reformacja. Warszawa: WP.

Heller-Kubica, G. 1996. Luteranie na Ślasku Cieszyńskim. Studium historyczno-socjologiczne. Bielsko-Biała: Wydawnictwo Augustana.

Różańska, A. 2015. Edukacja religijna młodzieży w warunkach pluralizmu religijnego w wybranych krajach Europy Środkowo-Wschodniej (Grupa Wyszehradzka: Polska, Czechy, Stowacja, Wegry) - studium porównawcze. Toruń: Wydawnictwo Adam Marszałek.

Strona Kościoła Ewangelicko-Augsburskiego luter2017.pl (2017). 1517-2017, 500 lat Reformacji. Rok Kościoła 2016, tylko Chrystus, tylko wiara, tylko łaska, tylko Pismo. Dekada Reformacji. http://luter2017.pl/dekada/ (20.01.2017).

Strona Kościoła Ewangelicko-Augsburskiego luter2017.pl (2017). 1517-2017, 500 lat Reformacji. Rok Kościoła 2016, tylko Chrystus, tylko wiara, tylko łaska, tylko Pismo. Rok Reformacji 2017 rozpoczęty. http://luter2017.pl/ reformacji-2017-rozpoczety/ (20.01.2017).

Uglorz, M. 1995. Marcin Luter. Ojciec Reformacji. Bielsko-Biała: Wydawnictwo Augustana.

Wojak, T. 1995. Zarys historii Kościoła. Bielsko-Biała: Wydawnictwo Augustana.

Zieliński, T. (red.) 1992. Z historii Kościoła Ewangelickiego na Śląsku Cieszyńskim. Katowice: Dom Wydawniczy i Księgarski Didache. 


\section{The Reformation viewed by upper-secondary school learners in Cieszyn Silesia}

Abstract: This article is about perception of the values that the Reformation has been and still is promoting. I present the background and the origin of reformation movement in Europe and Polish territories, showing its dynamics and scope of impact. I described the essence of Reformation's pillars in the theological sense as well as perception of the Reformation's heritage by contemporary high school students, on the basis of conducted, categorized interview.

Keywords: perception of the Reformation's values, youth from the Polish-Czech borderland 